\title{
Response of durum wheat and associated weeds to some weeds control treatments under various seeding rates
}

\author{
G.G. Darwish ${ }^{1}$, S.A.A. AtaAllah ${ }^{1}$, S.Sh. Abdullah ${ }^{2}$, A.A.M. Younis ${ }^{3}$ \\ 1 Agronomy Department, Faculty of Agriculture, Minia University, Egypt \\ 2 Agronomy Department, Faculty of Agriculture, Sohag University, Egypt (E-mail: s.shalaby13@gmail.com) 3 \\ Al Azhar Education, Sohag, Egypt
}

\begin{abstract}
Weeds are one of the biggest obstacles to upgrade wheat production. Using the proper seeding rate and applying effective weeding program are among the factors suppress weeds, improve wheat grain yield and quality. This study aimed at evaluating the effects of weed control treatments i.e. Bromoxynil (Brominal) (24\% EC), Clodinafop-Propargyl (Topik) (15\% WP), Brominal + Topik, hand weeding as compared to unweeding check; four seeding rates viz. $60,80,100$ and $120 \mathrm{~kg} /$ feddan (fed) ${ }^{*}$ and their interaction on productivity of durum wheat and associated weeds. The results revealed that increasing seeding rate from 60 to $120 \mathrm{~kg} / \mathrm{fed}$ caused great reduction in dry weights of weeds. Brominal + Topik gave the highest reduction in dry weight of grassy, broadleaf and total weeds. Applying Brominal + Topikwith 100 or $120 \mathrm{~kg} / \mathrm{fed}$ seeding rate was the best combination for controlling weeds. Increasing seeding rates from 60 to $100 \mathrm{~kg} / \mathrm{fed}$ significantly increased number of spikes $/ \mathrm{m}^{2}$ and grains/spike in one season only. Weight of 1000 grains was decreased with increasing seeding rate from 60 to $120 \mathrm{~kg} / \mathrm{fed}$. Grain yield was increased when seeding rate increased from 60 to 100 $\mathrm{kg} / \mathrm{fed}$. Brominal + Topik treatment was superior in improving most wheat yield components, grain and straw yields. In practice grain yield increased by 43 and $38 \%$ as compared to the unweeded plots in first and second seasons, respectively. Using 80 or $100 \mathrm{~kg} /$ fed seeding rate with Brominal + Topik as post emergence herbicides would be recommended for achieving high grain yield $(21 \mathrm{ardeb} / \mathrm{fed})^{* *}$ under similar conditions of desert reclaimed soil highly infested by weeds.
\end{abstract}

Key words: Durum wheat, Seeding rate, Bromoxynil, Clodinafop-Propargyl, Weed management

\section{Introduction}

Wheat is the first staple foodcrop in Egypt where it provides the Egyptians with $19 \%$ of the total foodrequirments, $31 \%$ of calories and $38 \%$ of proteins*. Durum wheat (Triticumdurum, Desf.) is used mainly for producing semolina used in making macaroni and other food stuff. It is intensively cultivated in upper Egypt due to its good heat tolerance and represents $9.3 \%$ of total wheat area (3.393 million fed $)^{*}$.

$* 1 \mathrm{fed}=4200 \mathrm{~m}^{2}=0.42 \mathrm{ha} \quad * * 1 \mathrm{ardeb}=150 \mathrm{~kg}$ of wheat grains, $1 \mathrm{ardeb} / \mathrm{fed}=0.3571$ ton $/$ ha

Increasing the harvested area, yield per unit area and/or decreasing yield losses are the main national targets for improving wheat production to meet the food demands of the increasing population. Wheat grain production including durum wheat has noticeably increased in the last two decades, however, the domestic production covered only $54.5 \%$ of the needed supply** and $68.3 \%$ from the actual amounts used for food in 2014*. Although several high yielding wheat varieties have been developed and released to the farmers, the national average yield (18.67 ardeb/fed) is below (23.02 ardeb/fed) in some extension fields (El-Bana et al., 2013). Accordingly, a good variety to exert its high yielding potentiality needs to be grown at suitable environment and to receive all crop management at the optimum levels.

Using the proper seeding rate and applying the effective weed control programs are among the factors suppressing weeds, improving growth and yield for wheat. Weeds are a major obstacle to wheat production. Yield losses caused by weeds may be due to their strong competition with crop plants for growth factors i.e. water, light, nutrients, space and $\mathrm{CO}_{2}$ or their allelopathic effects. Weeds not only cause a yield reduction of $(\Gamma \cdot . \vee \%$ as reported by Chopra et al., 1999), but also decrease the yield quality, hinder harvesting and increase production costs. Hand weeding is a common practice of weed control in wheat fields in Egypt. This method is still in use to control weeds particularly when wheat is grown for seed production and weeds are in low densities or may be used to complete the action of inadequate chemical control. Hand weeding in wheat was effective in controlling all weeds in terms of reducing weed density (Singh et al., 1989; Abd ElHamid, 1998), fresh biomass (Nassar, 2003; Mekky et al., 2007) and dry weight (Abuziena et al., 2008). In most cases, hand weeding improved wheat yield components and increased grain yield (Verma and Srivastava, 1989; Helal, 2003).

Chemical weed control in wheat production is easier, cheaper and takes less time than hand weeding. Bromoxynil is an effective herbicide 
against many small annual broadleaf weeds. It is primarily a contact herbicide and, therefore, it is ineffective against perennials and can be used safely on wheat seedling (Appleby, 1987). Clodinafoppropargyl is a selective herbicide used widely to control grassy weeds in wheat. It is excellent in suppressing weeds, reducing their biomass and its effect is translated directly to the yield components and finally increase grain yield (Yehia et al., 1998; Weiner et al., 2001; Bibi et al., 2008).

Establishment of adequate wheat stands by sowing the proper seeding rate is necessary for high yields which increase returns from other production inputs and may decrease the need for chemical weed control (Paulsen, 1987; Murphy et al., 1996). It is reported that increasing seeding rate decreased weed densities, fresh weight and dry matter (Salem et al., 1994; Burnett et al., 2003). Increasing seeding rate increased plant height, number of spikes, grain and straw yields per unit area, while number of grains per spike and 1000 grain weight were decreased with the higher seeding rates (Salem, 1999; Arduini et al., 2006). Poor stands, on the other hand, limit grain yields through the weeds inter-specific competition and may increase the need for other management inputs. Reviewing literature on wheat management in Egypt showed that most of available information is dealing with bread wheat, but few dealt with durum wheat. Thus, the objective of this study was to evaluate some weed control methods, different seeding rates and their interactions on the performance of cv. Sohag 3 durum wheat and associated weeds under new reclaimed desert land conditions in Sohag Governorate.

\section{Materials and Methods}

A two-year field experiment was carried out at Alkawthar Farm of Faculty of Agriculture, Sohag University, Egypt during 2004/05 and 2005/06 seasons. The top-soil $(0-30 \mathrm{~cm})$ of the experimental farm was Sandy-clay with $\mathrm{pH}(1: 1) 7.6$, EC (1:5) $0.65 \mathrm{dS} / \mathrm{m}$ and having $2.63 \%$ organic matter and $0.17 \%$ total N. This work aimed at evaluating five weed control treatments under four seeding rates and their interactions on productivity of durum wheat and associated weeds. The used seeding rates were 60 , 80,100 and $120 \mathrm{~kg} / \mathrm{fed}$. The weeding treatments were as follows:

1. Hand weeding twice at 30 and 45 days after sowing (DAS).

2. Bromoxynil (3,5 - dibromo - 4 - hydroxyl benzonitrile ), known commercially as Brominal, ( $24 \%$ EC), applied at the rate of $1.0 \mathrm{~L} / \mathrm{fed}$, at 4-5 wheat- leaf stage.

3. Clodinafop-Propargyl \{2-propnil [®-2-(4-5chloro-3-fluoro-2 pyridnyloxy) phenoxy] propionate\}, known commercially as Topik, (15\% WP), applied at the rate of $140 \mathrm{~g} / \mathrm{fed}$ at 45 DAS.
4. Brominal at the rate of $1.0 \mathrm{~L} / \mathrm{fed}+$ Topik at the rate of $140 \mathrm{~g} / \mathrm{fed}$ applied at the same times as for each alone.

5. Control (unweeding check).

*According to Economic Affairs Sector, Ministry of Agriculture and Land Reclamation, 2015, Egypt.

$* *=$ domestic production + imports + stock in year first - stock in year end - exports

The herbicides were sprayed using a 20 L- knapsack sprayer with one nozzle.

A randomized complete block design (RCBD) in split-plot arrangement with four replicates was used. Seeding rates were arranged randomly in the main plots, while the subplots were randomly assigned to weed control treatments.

Seeds of durum wheat cv. Sohag 3 were drilled manually into $3-5 \mathrm{~cm}$-deep rows on $1^{\text {st }}$ and $3^{\text {rd }}$ Dec. in the first and second seasons, respectively.

The experimental area was divided into $10.5 \mathrm{~m}^{2}(3 \mathrm{~m}$ x $3.5 \mathrm{~m}$ )- subplots; each consisted of 15 rows 20 cm apart.

Phosphorus fertilizer in the form of calcium superphosphate $\left(15.5 \% \mathrm{P}_{2} \mathrm{O}_{5}\right)$ at a rate of $150 \mathrm{~kg} / \mathrm{fed}$ was added at sowing. Nitrogen fertilizer was added in the form of urea $(46.5 \% \mathrm{~N})$ at a rate of $112 \mathrm{~kg}$ $\mathrm{N} /$ fed splitted into three portions, the first one $(20 \%)$ was applied at sowing, the second (40\%) at tillering and the third $(40 \%)$ at stem-elongation stage. Other cultural practices were performed as recommended for wheat production in the area.

\section{Data recorded:}

\section{Weeds:}

Weeds were hand pulled from one square meter in each subplot at 75 DAS, then separated to narrow leaf (grasses) and broadleaf weeds. Weeds were air dried for seven days and then oven dried at $70^{\circ} \mathrm{C}$ until a constant weight, then dry weight of grassy weeds, broadleaf weeds and total weeds were recorded in $\mathrm{g} / \mathrm{m}^{2}$

\section{Wheat traits:}

\section{A. Vegetative characteristics:}

At 100 DAS, number of stems (main stem and tillers $) / 0.5 \mathrm{~m}^{2}$; plant height $(\mathrm{cm})$ and flag leaf area $\left(\mathrm{cm}^{2}\right)$ were measured on a 10 -stems sample. Flag leaf area was calculated by multiplying blade length * maximum blade width * 0.75 according to Richards (1983).

\section{B. Yield and yield components:}

At harvest, plants from $0.25 \mathrm{~m}^{2}$ area were cut at soil surface to measure and record the following traits: 
1) Number of stems (main stem and tillers) $/ \mathrm{m}^{2}$. 2) Number of spikes $/ \mathrm{m}^{2}$. 3) Plant height (cm) of 10 stems. 4) Spike length (cm) and grain number/spike of 10 spikes. 5) Weight of 1000 grains (g), as average of three samples.

At harvest, plants on $4 \mathrm{~m}^{2}$ internal area (other than the previous $0.25 \mathrm{~m}^{2}$ area) in each subplot were cut at soil surface to estimate grain yield (ardeb/fed) and biological yield (ton/fed $=0.42$ ton/ha). Straw yield (ton/fed) was calculated by subtracting grain yield from biological yield.

C. Protein content (\%):

Nitrogen determination was carried out by the improved Kjeldhal method of A.O.A.C. (1980) and Protein content (\%) was calculated by multiplying $\mathrm{N} \% * 5.7$

\section{Statistical analysis:-}

All data of each season were statistically analyzed according to the technique of analysis of variance (ANOVA) by MSTAT-C software package. Least significant difference (LSD) test at 5\% level of significance was used for treatment means separation according to Gomez and Gomez (1984).

\section{Results and discussion}

\section{Dry weight of grasses, broadleaf and total weeds at 75 DAS:}

Weeds survey exhibited that the prevalent grassy weed species associated with wheat crop plots in both seasons were AvenafatuaL., Cyperuslongus L. and Loliumtemulentum L. Meanwhile, the broadleaf weeds were Ammimajus L., Medicagopolymorpha L., Rumexdentatus L., Plantago major L., SonchusoleraceusL. and Malvaparviflora $\mathrm{L}$

Data in Table 1 indicate that the dry weights of grassy, broadleaf and total weeds at 75 DAS were significantly decreased with increasing seeding rate from 60 to $120 \mathrm{~kg} / \mathrm{fed}$ in both seasons, except for broadleaf and total weeds in the second season. As an average over the two seasons, increasing the seed rate from 60 to $120 \mathrm{~kg} / \mathrm{fed}$ caused a reduction in dry weight acounted for 46.3, 34.1, and $37.7 \%$ of grassy, broadleaf and total weeds, respectively. This effective action of the increased seeding rate on reduction of dry weight of weeds might be due to the competition of high densities of wheat plants on growth factors against both broadleaf and grassy weeds. These results are in consistence with those obtained by Burnett et al. (2003). Weed control treatments significantly reduced dry weight of grassy, broadleaf and total weeds as compared to the check (unweeded) in both seasons (Table1). The application of Brominal at $1.0 \mathrm{~L}$./fed + Topik at 140 $\mathrm{g} / \mathrm{fed}$ (Brominal + Topik) gave the highest reduction in the dry weight of narrow leaved, broad leaved and total weeds at 75 DAS. This reduction in dry weight of grassy, broadleaf and total weeds caused by Brominal + Topik compared to the check amounted to $91.7,77$ and $81.7 \%$ as averages of the two seasons.

Since Brominal is a selective herbicide specific for broad leaved weeds and Topik is a selective herbicide for narrow leaved weeds, then using Brominal + Topik together suppressed a wide range of both narrow and broad leaved weeds. These results are in harmony with those reported byAtallaet al. (1998) and Nassar (2003).

A significant effect of the interaction between seeding rate and weed control treatments on narrow leaved and total weeds at 75 DAS was observed in both seasons (Table1). Using (Brominal + Topik) with seeding rate of $120 \mathrm{~kg} / \mathrm{fed}$ gave the greatest reduction in dry weight of narrow leaved and total weeds. Yet, the differences in weed dry weights between 100 or $120 \mathrm{~kg} / \mathrm{fed}$ seeding rates were insignificant with using the same weed control treatment.

II- Wheat vegetative traits, yield, yield components and protein content.

Results on number of stems (main stems + tillers) $/ \mathrm{m}^{2}$ at $100 \mathrm{DAS}$ and at harvest (Tables 2, 3) indicate that this trait almost increased with increasing seeding rates from $60 \mathrm{~kg}$ up to $120 \mathrm{~kg} / \mathrm{fed}$ at $100 \mathrm{DAS}$ and up to $100 \mathrm{Kg} / \mathrm{fed}$ at harvest as shown. This observation might be due to the fact that the increased seeding rates gave higher plant densities which produced more stems $/ \mathrm{m}^{2}$. However, as wheat plants grown from 100 DAS to harvest, the intra-specific competition on growth factors increased. This phenomenon could interpret the why highest seeding rate of $120 \mathrm{~kg} / \mathrm{fed}$ gave lesser stems compared to $100 \mathrm{~kg} / \mathrm{fed}$ seeding rate at harvest in both seasons.

Weed control treatments exerted significant effects on stems number $/ \mathrm{m}^{2}$ at 100 DAS and at harvest in both seasons. Brominal + Topiktreatments gave greater number of stems, while the least number of stems resulted from the unweeded check (Tables 2, 3). In this respect, chemical weed control with Brominal or Topik, alone or in combination exceeded mechanical (hand weeding) treatment. Such result might be due to the herbicidal effect which could minimize both weeds densities and their inter-specific competition with wheat plants which allowed plants to be more prolific in tillering.

Plant height measured at 100 DAS and at harvest was significantly increased with increasing seeding rate from 60 to $120 \mathrm{~kg} / \mathrm{fed}$ in both seasons (Tables 2, 3). The higher seeding rates resulted in higher plant densities with taller plants due to that shading caused by the dense populations might induce some growth promoters as auxins or gibberellic acid which was responsbile for this result. Similar results on number of stems $/ \mathrm{m}^{2}$ and plant height as affected by seeding rate were reported by Salem (1999) and El-Bana (2000). 
The interaction effect of weed control treatments and seeding rate on number of stems $/ \mathrm{m}^{2}$ at 100 DAS was significant in the two seasons of the study. The combined treatment of Brominal + Topik and seeding rate of $120 \mathrm{~kg} / \mathrm{fed}$ (in the first season) or $100 \mathrm{~kg} / \mathrm{fed}$ produced the higher number of stems (in the second season) compared to the unweeded plots with seeding rate of $60 \mathrm{~kg} / \mathrm{fed}$ which resulted in the least number of stems in both seasons.

Flag leaf area at 100 DAS (Table 2) increased significantly with increasing seeding rate from 60 to $100 \mathrm{~kg} / \mathrm{fed}$ in the first season only. Weeding treatments gave significant increases in flag leaf area as compared to the check which produced the least flag leaf area in both seasons.

\section{Yield and Yield components}

Spike length didn't change much with changing weed treatments, seeding rates or their interaction in both seasons except for weeding treatments in the second season (Table 3). However, the Brominal + Topik treatment gave the longest spikes. It seems that such trait is less affected be the environmental changes.

Results of the two seasons on grain yield components i.e. spike number $/ \mathrm{m}^{2}$, grain number/spike and 1000-grain weight (g) are presented in Table 4. Number of spikes $/ \mathrm{m}^{2}$ increased with increasing seeding rate from 60 up to $100 \mathrm{~kg} / \mathrm{fed}$ significantly in the first season only. It seems that using $100 \mathrm{~kg} /$ fed seeding rate was the optimal for this trait. In contrast, the $120 \mathrm{~kg} / \mathrm{fed}$ seeding rate increased the number of spikes that increased competition among wheat plants which in turn retarded their ability to set more effective tillers and consequently more spikes. These results are in line with those obtained by Salem (1999), El-Bana (2000) and Arduini et al. (2006). Weed control treatments revealed significant effects in both seasons on this important yield component. Using of Brominal or Topik herbicides, eitherweed control alone or in combination produced more spikes/m2 as compared to the unweeded or hand weeding treatments. The Brominal + Topik treatment gave $20.5 \%$ more spikes than hand weeding, as an average of the two seasons. Suppressing weeds in the treated plots with herbicides or by hand weeding might give wheat plants more area to grow better and produce more effective bearing tillers spikes.

Number of grains/spike increased and was significant in the second season with increasing seed rate from $60 \mathrm{up}$ to $100 \mathrm{~kg} / \mathrm{fed}$. This result might be due to the fact that the high seed rate increases the number of main stems and decreases the number of tillers (Gardner et al. 1990), consequently, the main stem spikes produce more grains. Results on the number of grains/spike as affected by seeding rate didn't take the same trend as reported previously by Salem (1999) and Arduini et al. (2006). Weed control treatments showed significant differences in number of grains in both seasons. Application of Brominal + Topik treatment yielded more grains/spike compared to other weeding treatments. Yet, application of Brominal alone came the second in this respect. This result was in agreement with those obtained by Yehia et al. (1998), and Bibi et al. (2008).

Weight of 1000 grains, however, responded adversely compared to the previous yield components where its value almost decreased with increasing seeding rate. This result might be due to the compensation phenomenon among wheat yield components. Slafer et al. (1996) reported that grain weight showed only little or negligible effect and, in some trials, declined with increased yield. Similar results were obtained by Hassan (1999) and Abd-ElSamie (2001). Meanwhile weed control treatments showed significant increases an 1000 grain weight compared to unweeded treatment. Hand weeding was the first in this respect, while Brominal + Topik treatment came the second with insignificant difference between them. This result was in line with those obtained by Nagla (1998) and Anaam (2003).

Data on grain yield as affected by seeding rate, weed control treatments and their interaction in 2004/05 and 2005/06 are presented in Table 5. In regard to the effect of seeding rate, grain yield was significantly increased with increasing seeding rate from 60 to $80 \mathrm{~kg} / \mathrm{fed}$ which were 18.38 and 18.42 ardeb/fed in first and second seasons, respectively. However, the additional increases in grain yield due to the seed rate of $100 \mathrm{~kg} / \mathrm{fed}$ were not significant as compared to the $80 \mathrm{~kg} / \mathrm{fed}$ seed rate. Such result was expected since the major yield components (number of spikes $/ \mathrm{m}^{2}$ and grains number/spike) took similar trend. Hence, increasing the seeding rate up to 120 $\mathrm{kg} / \mathrm{fed}$ resulted in grain yield reduction as compared to 80 or $100 \mathrm{~kg} / \mathrm{fed}$ rates. The intra-specific competition among wheat plants on light, nutrients, water and other growth factors might be the main reason for such yield reduction caused by the highest seeding rate. These results are in consistence with those reported by Murphy et al. (1996), Zohry et al. (1998) and Staggenborg et al. (2003). Weed control treatments exhibited significant increases on grain yield/fed as compared to unweeded plots in both seasons. Brominal + Topik treatment achieved the highest grain yield of 20.02 and had (43\% higher than the check in the first season) and 19.74 (38\% higher than the check in the second season) ardeb/fed. Nevertheless, Brominal or Topik each alone came the second and the third on the rank for grain yields in both seasons. In this respect, results clearly indicated that chemical weed control was more effective than hand weeding for achieving higher grain yields. Ormeno (1992) and Mekky et al. (2007) reported similar findings on grain yield as affected by chemical and mechanical weed control. The interaction effect of seeding rate and weeding 
treatments on grain yield was significant in both seasons. The treatment of Brominal + Topik with $100 \mathrm{~kg} / \mathrm{fed}$ seeding rate resulted in the highest grain yield/fed, with the difference in grain yield between 80 and $100 \mathrm{~kg} / \mathrm{fed}$ rates was insignificant in both seasons. This result suggests that sowing $80 \mathrm{~kg} / \mathrm{fed}$ seeding rate with controlling weeds using Brominal + Topic was the best combination for achieving high grain yields under similar conditions.

Effect on protein content was insignificantly affected by seeding rates, weeding treatments and their interaction in the first season (Table 5). However, weed control treatments and their interaction with seeding rates showed significant effect on this important quality trait of wheat grains in the second season. The highest protein content $(13.5 \%)$ was obtained from applying Brominal + Topik treatment under $100 \mathrm{~kg} / \mathrm{fed}$ seeding rate with no significant difference between 100 or $80 \mathrm{~kg} / \mathrm{fed}$ seeding rates. The lowest value of protein content was produced from using the lowest seeding rate of $60 \mathrm{~kg} / \mathrm{fed}$ with unweeded treatment in both seasons. Similar results were obtained by Puri et al. (1989) and Abdulkarim et al. (2015). While the results of weed control treatments are on the contrary with those of El-Desoky (1990), who reported that chemical and mechanical weed control did not significantly affect protein content in wheat grains.

Straw yield was significantly increased as seeding rate increased from 60 up to $120 \mathrm{~kg} / \mathrm{fed}$ in first season and up to $100 \mathrm{~kg} / \mathrm{fed}$ in the second season (Table 5). The increases in number of plants per unit area caused by the higher seeding rates might be the direct reason for such increases in straw yields. Similar results were reported by Salem (1999). Weeding treatments significantly affected straw yield in both seasons. The highest straw yield (4.47 ton/fed) resulted from Brominal + Topik treatment, followed by Brominal treatment which gave $3.85 \mathrm{ton} / \mathrm{fed}$, as an average of the two seasons. Similar to grain yield results, the interaction effect of seeding rate and weeding treatments on straw yield was significant in both seasons. The highest straw yield (5.53 ton/fed) was resulted from application of Brominal + Topik herbicides with using of 100 $\mathrm{kg} / \mathrm{fed}$ seeding rate, as an average of both seasons. 


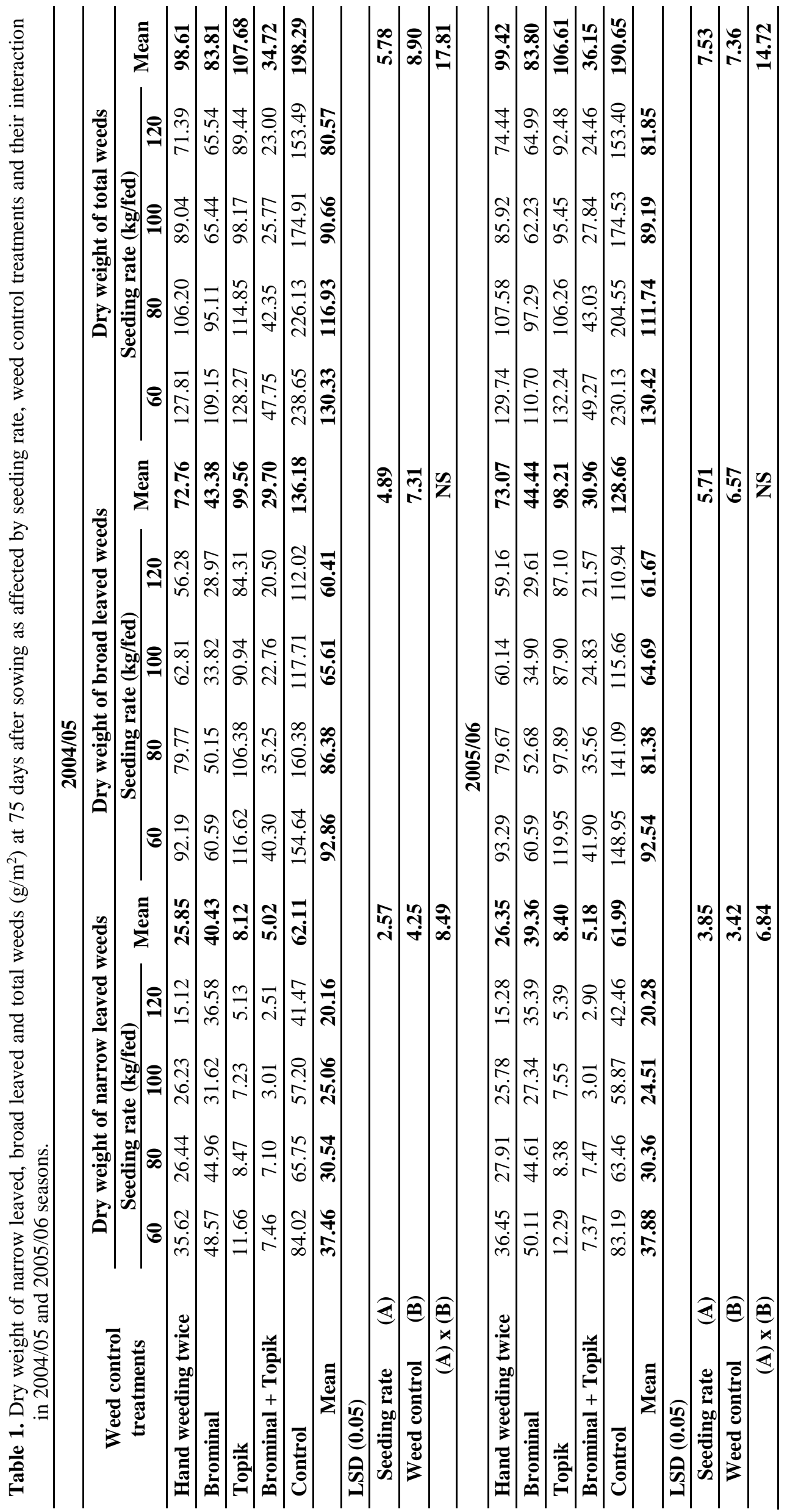




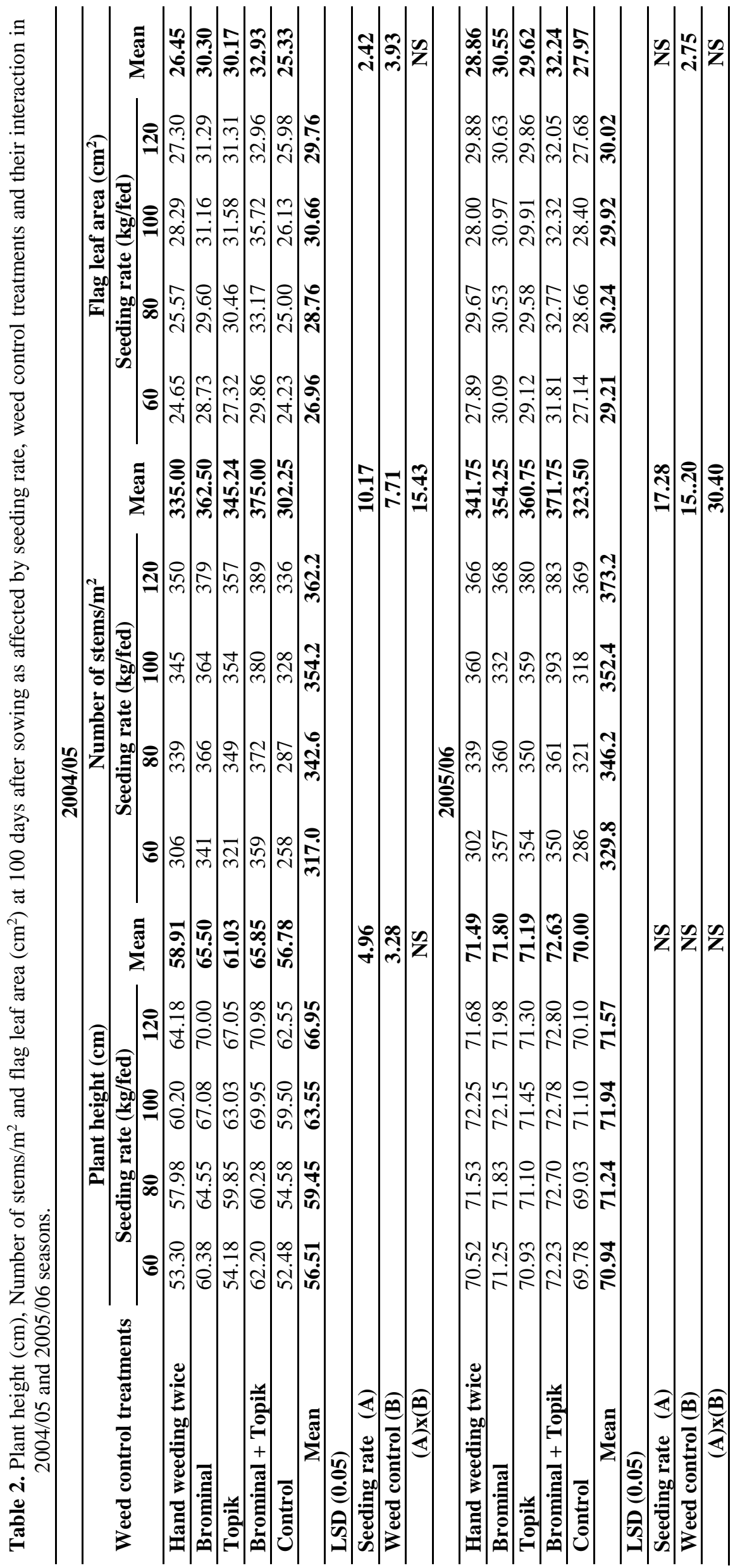




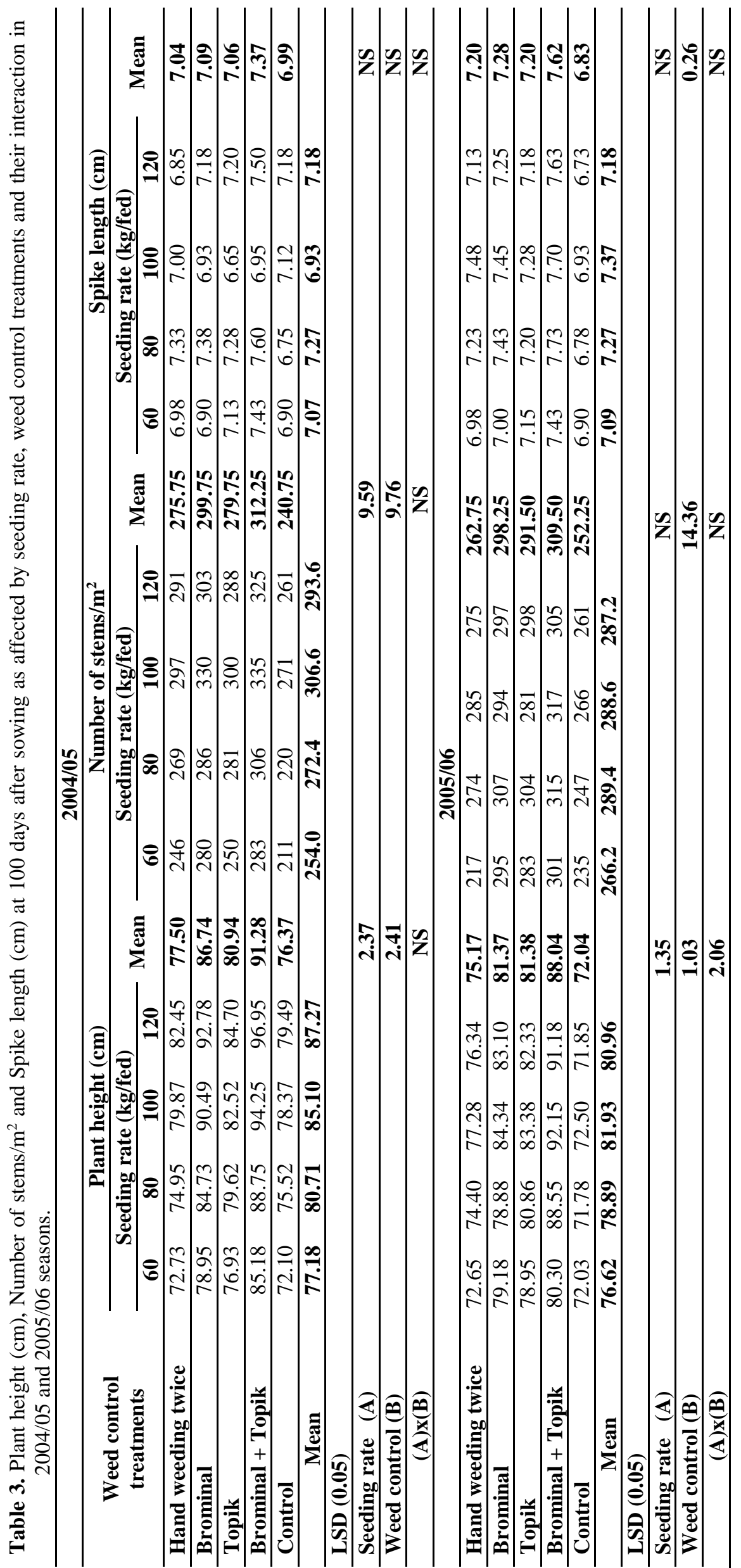




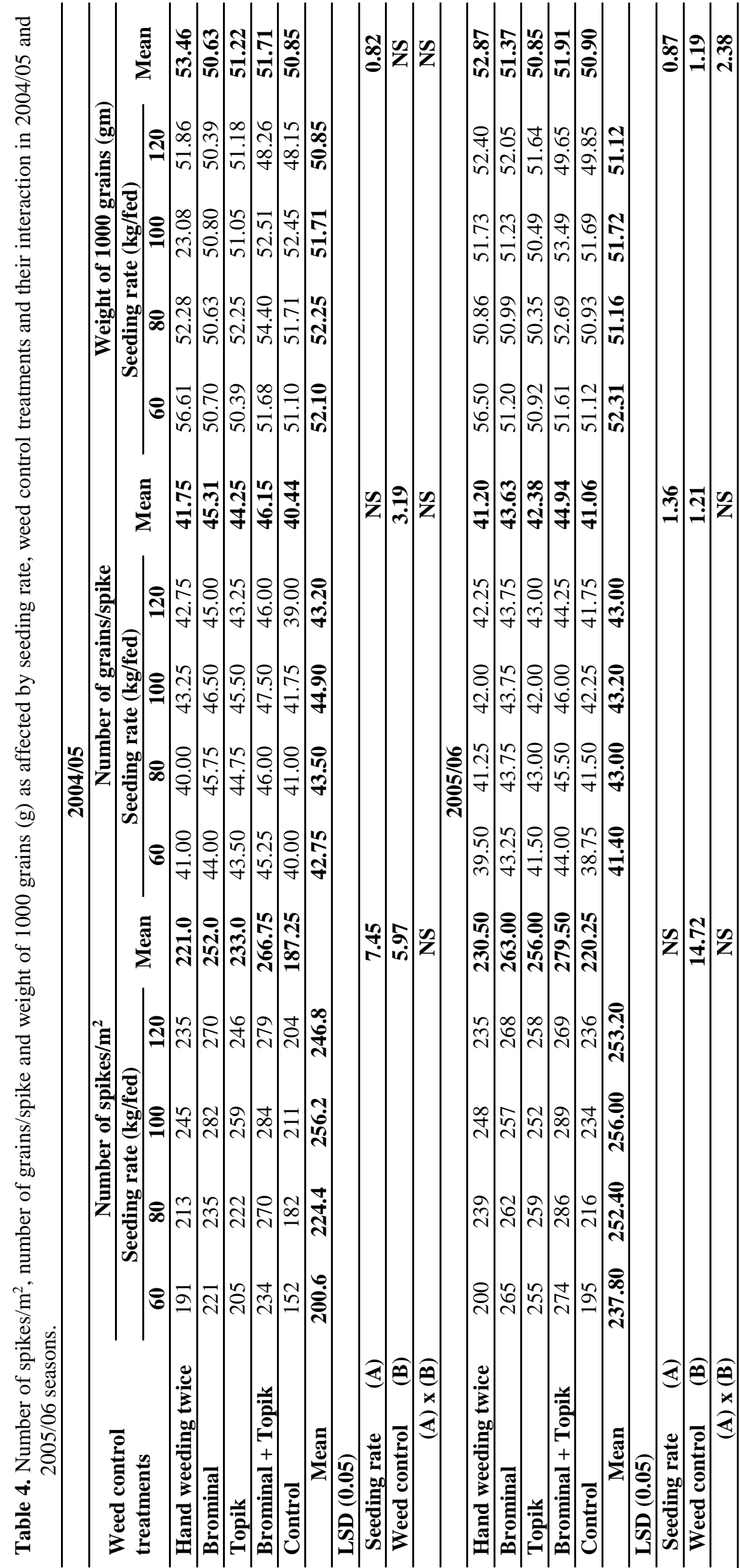









\section{References}

A.O.A.C. (1980). Official Methods of Analysis Association of Agricultural Chemists. Published by the A.O.A.C., Box 540, Washington, D.C., USA.

Abd El-Hamid, M.M. (1998). Effect of weed control and the preceding summer crop on the annual grassy weeds and wheat grain yield. Assiut. J. Agric. Sci. 24(3): 115-121.

Abd El-Samie, F.S. (2001). Integrated weed management in wheat. Mimufya. J. Agric. Res. 20(3): 619-633.

Abdulkarim, J.; T. Tana and F. Eticha (2015). Response of bread wheat (Triticumaestivum L.) varieties to seeding rates at Kulumas, South Eastern Ethiopia. Asian J. Plant Sci. 14 (2): 5058.

Abouziena, A.F.; A.A. ShararaFaida and E.R. Eldesoki (2008). Efficacy of cultivar selectivity and weed control treatments on wheat yield and associated weeds in sandy soils. World j. Agric. Sci. 4 (3): 384-389.

Anaam, H. Galal (2003). Response of wheat and its associated weeds to sowing methods, rates and weed control treatments. Assiut J. of Agric. Sci., 34 (5): 77-98.

Appleby, A. P. (1987). Weed control in wheat. In E.G. Heyne (ed.) Wheat and wheat improvement. 2nd. Agronomy 13: 396-415. ASA, Madison, Wisconsin, USA.

Arduini, I.; A. Masoni; L. Ercoli and M. Mariotti (2006). Grain yield, dry matter, nitrogen accumulation and remobilization in durum wheat as affected by variety and seeding rate. European. J. Agron. 25(4): 309-318. (C.F. CAB Abstracts 2006).

Atalla, S.I; M.M. Abd El- Hamid and L.A. ElMashad (1998). Effect of some weed control treatments on weeds and yield of three wheat cultivars. J. Agric. Sci. Mansoura Univ., 23(8): 3583- 3590.

Bibi, Sh.; K.B. Marwat; G. Hassan and N.M. Khan (2008). Effect of herbicides and wheat population on control of weeds in wheat. Pak. J. Weed Sci. Res. 14 (3-4): 111-119.

Burnett, V.F.; J.H. Schneider and F.W. Dempsey (2003). Effect of seeding rate on organic wheat production and ryegrass density in northeast Victoria. Solutions for a better environment: Proceedings of the-11th-Australian-AgronomyConference,-Geelong,-Victoria, Australia, 2-6 February, 2003. (C.F. CAB Abstracts 2003).

Chopra, N.; H. Singh and H.P. Tripathi (1999). Critical Period of weed crop competition in wheat (Triticumaestivum L.). Indain J. Weed Sci. 31 (3-4): 151-154.

El-Bana A.A.; I.M. Sadeq and M.A. Mostafa. (2013). The final report: National Program for Raising Wheat Production and National Project of
Extension Fields. Agric. Res. Center, Minist. Agric. Land Reclaim., Egypt.

El-Bana, A.Y.A (2000). Effect of seeding rate and PK fertilizers levels on grain yield and yield attributes of wheat under newly cultivated sandy soil conditions. Zagazig J. Agric. Res. Vol. 27(5): 1161-1178.

El-Desoky, E.R. (1990). The influence of some herbicides mixtures on wheat and associated weeds. Ph.D. Thesis, Fac. Agric., Cario, Egypt.

Gardner, F.P.; R.B. Pearce and R.L. Mitchell (eds.). (1990). Vegetative Growth. P. 27 - 295. In Physiology of crop plants. 2nd ed. Iowa State Univ. Press, Ames, IA, USA.

Gomez, K.A. and A.A. Gomez (1984). Statistical Procedures for Agriculture Research. John Wiely and Sons. Inc. New York.

Hassan, A.A. (1999). Determination of optimum seeding rate for newly released wheat cultivars. Bull. Fac. Agric. Cairo Univ. 50(4): 621-638.

Helal, M.H.A. (2003). Effect of population and weed control on yield of wheat. MS. Thesis, Fac. Agrci. Al-Azhar Univ., Egypt.

Mekky, M. S.; A.A. Mostfa and S.A. Elmajeed (2007). Effect of mechanical tillage system, wheat varieties and weed control treatments on weeds and wheat (Triticumaestivum, L.) productivity. Misr J. Agric. Eng., 24(1): 18-41 .

Murphy, S.D.; Y. Yakubu; S.F. Weise and C.J. Swanton (1996). Effect of planting patterns and inter-row cultivation on competition between corn (Zea mays) and late emerging weeds. Weed Science 44, 856-870.

Nagla, M.A. (1998). Effect of some new herbicides on wheat growth and associated weeds. Ms. Thesis, Fac. Agric, Cairo Univ., Egypt.

Nassar, A.N.M. (2003). Performance of some wheat varities with Clodinofop-propargyl herbicide on wild oat control and wheat productivity. Egypt. J. Appl. Sci., 18 (B8): 481-496.

Ormeno, N.J. (1992). Effect of wild oat (Avenafatua) on wheat production (Triticumaestivum L.) AgriculturaTecnica (Santigo), 52 (1): 25-31. (C.F. Weed Abst. 42 (1): 4606, 1993).

Paulsen, G.M. (1987). Wheat stand establishment. In E.G. Heyne (ed.) Wheat and wheat improvement. 2nd. Agronomy 13: 396-415. ASA, Madison, Wisconsin, USA.

Puri, Y.P.; M.F. Miller; R.N. Sah; K.G. Baghott; E. Fereres-Castel and R.D. Meyer (1989). Response surface analysis of the effects of seeding rates, N-rates and irrigation on durum wheat. II. Protein yield and grain quality. USA. California Phyton. Buenos. Aires. 49(1-2): 41-59 (C.F. CAB Abstracts 1989).

Richards, R.A. (1983). Manipulate of leaf area and its effect on grain yield in drought wheat. AssiutJ.Agric. Res. 34: 13-31.

Salem, M.A.M. (1999). Effect of sowing dates and seeding rates on productivity of three newly 
wheat cultivars (Triticumaestivum L.) J. Agric. Sci. Mansoura Univ. Vol. 24(9): 4379--4395.

Salem, M.A.M; A.A.A. Tantawy and Sh.A. Mokadem (1994). Effect of seeding rate and weed control methods on yield and yield components of wheat. Minia J. Agric. Res. 16(1): 143-155.

Singh, S.J.; S.K. Varma; K.K. Sinha and S.S. Mishra (1989). Comparative efficiency of cultural and chemical methods of weed control in wheat. Indian J. Agron. 34(2): 209-212.

Slafer, G.A.; D.F. Calderini and D.J. Miralles (1996) Yield components and compensation in wheat: pportunities for further increasing yield potential. In M.P. Reynolds; S. Rajaram and A. McNab. (eds.) Increasing yield potential in wheat, Breaking the barriers, CIMMYT.

Staggenborg, S.A.; D.A. Whitney; D.L. Fjell and J.P. Shroyer (2003). Seeding and nitrogen rates required to optimize winter wheat yields following grain sorghum and soybean. Agron. J. 95(2): 253-259.
Verma, U.N. and V.C. Srivastava (1989). Weed management in wheat under zero and optimum tillage conditions. Indian J. Agron. 34(2): 176179.

Weiner, J.; H.-W. Griepentrog and L. Kristensen (2001). Suppression of weeds by spring wheat Triticumaestivum increases with crop density and spatial uniformity. J. Applied Ecol. 38: 784-790.

Yehia, Z.R; H.R. El-Wekil; A.H. Ghonima and A.M. El-Shater (1998). Effect of some new selective herbicides on wild oats control in wheat fields. NVRSRP for Wild Oates Control in Cereals and some other Winter Crops. Egypt, 6th Ann. Meet. Cairo Egypt. 6-11 Sept.: 101-106.

Zohry, A.A.; M.A. Haikel and F.A. Zahran (1998). Influences of seed rates and nitrogen sources on wheat plant grown in reclaimed soil under sprinkler irrigation system. J. Agric. Sci. Mansoura Univ. 23(11): 4751-4759.

$$
\begin{aligned}
& \text { استجابة قمح الايورم والحشائش المصاحبة له لبعض معاملات مكافحة الحشائش تحت معدلات تقاوى مختلفة }
\end{aligned}
$$

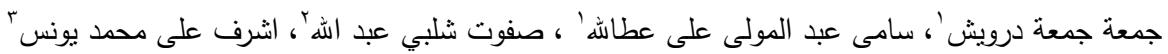

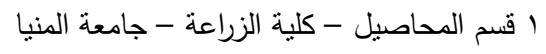

$$
\begin{aligned}
& \text { r ق بم المحاصيل - كلية الزراعة - جامعة سوهاج } \\
& \text { r التعليم الأزهري بسوهاج }
\end{aligned}
$$

\section{الملخص العربي}

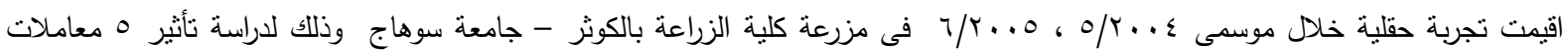

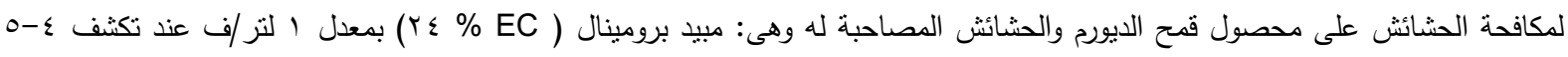

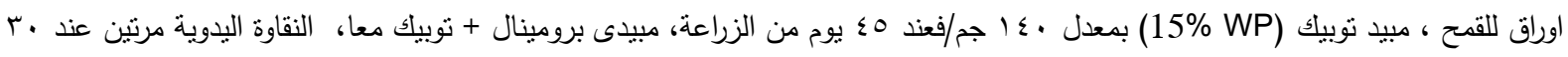

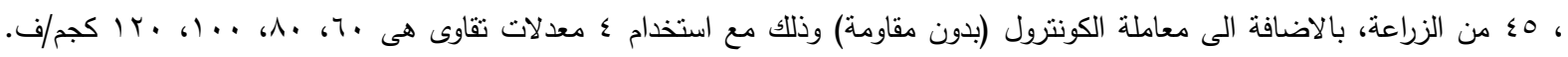

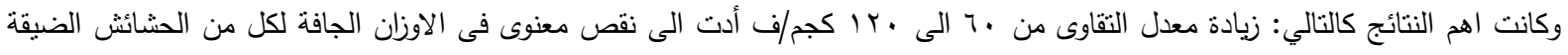
والعريضة والكلية عند هV يوم من الزراعة فى الموسم الأول والحثائش ضيقة الاوراق فقلط في الموسم الثانى حيث كان النقص فى اوزان

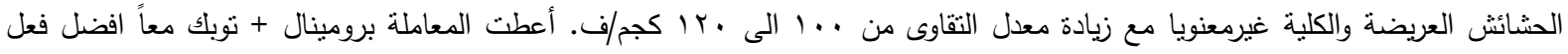

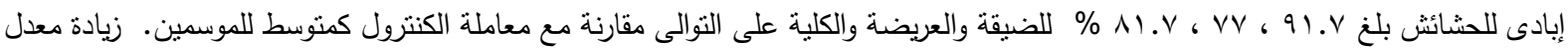

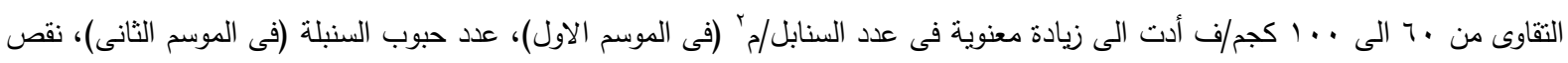

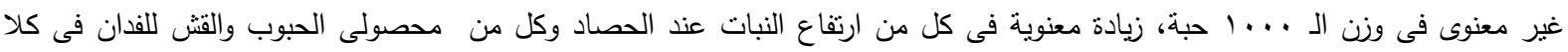

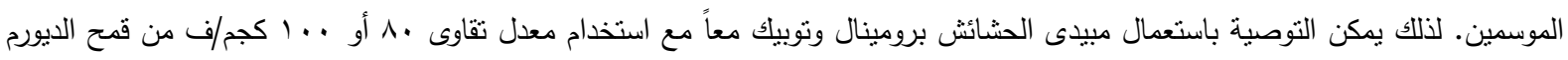

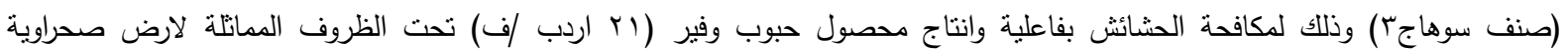

